\title{
ランドサットデータによる内モンゴル半乾燥地帯における 土地被覆変化と砂漠化の解析

\author{
ANALYSIS OF LAND COVER CHANGE AND DESERTIFICATION IN \\ INNER MONGOLIA SEMIARID REGION BY LANDSAT DATA
}

\author{
奥 倫*1, 斉藤郁雄*2, 石 原 修*3 \\ Lun AO, Ikuo SAITO and Osamu ISHIHARA
}

\begin{abstract}
The purpose of the present study is to estimate land cover change and desertification in Inner Mongolia semiarid region using Landsat data and the survey data of land use condition, and the land cover classification maps of summer in 1986, 1994 and 2002 were created. The vegetation change tendency of the different vegetation regions were estimated by the spectrum analysis of the bands characteristic, and the texture analysis of the spatial feature change of land is applied to desertified land. Based on the results, the enforcement effect of land use plan advanced by Inner government was evaluated.
\end{abstract}

\section{Keywords : Land Cover, Yellow River, Landsat, Desertification}

土地被覆，黄河，ランドサット，砂漠化

\section{1.はじめに}

乾燥、半乾燥地帯は、気候の変動や人間活動により環境生態系が 砂漠化・土地荒廃へ進展する危険性が極めて高い地域である。砂漠 化のような半乾檈地带特有の広大な環境変化を把握するためには、 人工衛星データを解析することが有効であり、重要な研究課題とな っている。衛星りモートセンシングデータによる中国内モンゴル自 治区砂漠地带における土地被覆変化、土地荒廃・砂漠化に関する調 查研究も行われている。立入ら ${ }^{11}$ は時系列衛星画像を用いた内モン ゴル北東部のコルチン砂地における砂漠化実態を推定している。秋 山ら ${ }^{2}$ はランドサット TM データの解析により内モンゴルシリンコ ル草原における草原退化や砂地の増加など生態環境覀化原因を分析 している。また、時系列衛星データから砂漠地帯の植生量遷移や砂 漠化の進展を解析した研究事例が数多くある ${ }^{314) 。}$

現在、半乾燥、乾燥地带にお引ける砂漠化対策の重要な課題として 現行の農村地帯における土地利用計画を検討することが重要な課題 となっている。内モンゴル西南部黄河流域では、現在、気候の変化 や近代化に伴う開発により、土地被覆変化と砂漠化が生じている。 農業生産の発展を果たしてきた一方で、砂漠化の進行にも悩まされ ている。

本研究では、内モンゴル黄河流域半乾暍地带の土地被覆変化と砂
漠化状況を解析するとともに、内モンゴル政府によって進められて いる土地利用計画の実施状況と効果を評価する。まず1986年、1994 年および 2002 年の夏期のランドサットTM、ETM+データを用い、3 時 期の土地被覆分類図を作成し、砂漠化地域と植生域の土地被覆変動 解析を行う。次に植生域から砂地に変動したエリアに対し、土地の 空間的特徴変化のテクスチヤ解析を行う。そして、エリアの各時期 の土地被覆状況とテクスチャ情報との関係について比較し、砂漠化 の実態を検討する。

また、砂漠化の進展は，地域の土地利用政策や人々の経済活動亡 密接に関連する。そこで、ランドサットデ一タから推定した結果と 現地土地利用変化調查統計資料との対応を比較検討する。これらの 検討によって、地域の耕地管理状況および草地の過開墾による土地 荒廃の状況を明らかにし、砂漠化防止対策の勃果について検証する。

\section{2. 研究対象領域}

本研究では、黄河の南に位圈する内モンゴル地区の七つの郷(日本 では郡と村の中間に相当する)を研究対象エリアとした（図 1 参照)。 この地域は東経 $109^{\circ} 05^{\prime}$ 加 $110^{\circ}$ 、北緯 $40^{\circ}$ から $40^{\circ} 25^{\prime}$ に位 置し、面積は約 $2520 \mathrm{k} \mathrm{m}^{2}$ 。黄河沿岸に分布している五つの郷では、 水利施設が整備され、恵まれた黄河の水凟源により豊かな灌溉農地
*1 能本大学工学部 外国人客貝研究員

*2 八代工業高等専門学校 教授・博士(工学)

*3 熊本大学工学部環境システム工学科 教授・工博
Guest Scholar Visiting Research Fellow, Faculty of Engineering, Kumamoto Univ. Prof., Yatsushiro National College of Technology, Dr. Eng.

Prof., Dept. of Architecture and Civil Engineering, Kumamoto Univ., Dr. Eng. 
が形成された。オルドス地区の最大な砂漠クブチ砂漠はこの地域の 中南部を貫通し、砂漠の周辺には草地と天水農地が分布している。 天水農地では灌睡手段がなく、雨水のみを利用している。ほとんど の草地は僅かな表土、表土が支える草の根によって維持されている が、この僅かな表土が開秏によって曝されるとその下部の砂が露出 し、植生被覆のない砂地になってしまう。1980 年後半から、この地 域では、草地の開坆により天水農地の面積が増加してきた。しかし、 地力維持の努力がなされていないため、土地の荒廃が進んでいる6)。

このような背景を基に内モンゴル自治区政府は、1990 年代から黄 河流域の生態系悪化・砂漠化を背景に退耕還草・還林の計画を進め てきた。これ㗻度の開躴を防ぐため、表土が流出したり砂漠化し たりした天水農地を草原や林に戻す政策である。研究対象とした七 つの拫は黄河流域の退耕還草プロジェクトモデル郷であり、1996 年 から、耕作地に適しない土地を退耕し、人工植草の土地利用調整に よる草地生態回復活動を進めている。このような施策によって、こ の地区では 1980 年代から土地被覆・土地利用が著しく変化してきた。

\section{3. 使用したランドサットデータ}

本研究では 1986 年 8 月 9 日と 1994 年 8 月 6 日に観測されたラン ドサット 5 号TMデータと 2002 年 8 月 20 日に観測されたランドサッ ト7号ETM+データを使用している。TM と ETM十データは内モンゴル 測絵局で 1988 年に編集された《内蒙古自治区地図集》のオルドス 地区地図 $(1: 400,000)$ を用いて幾何補正を行った。幾何補正されたデ

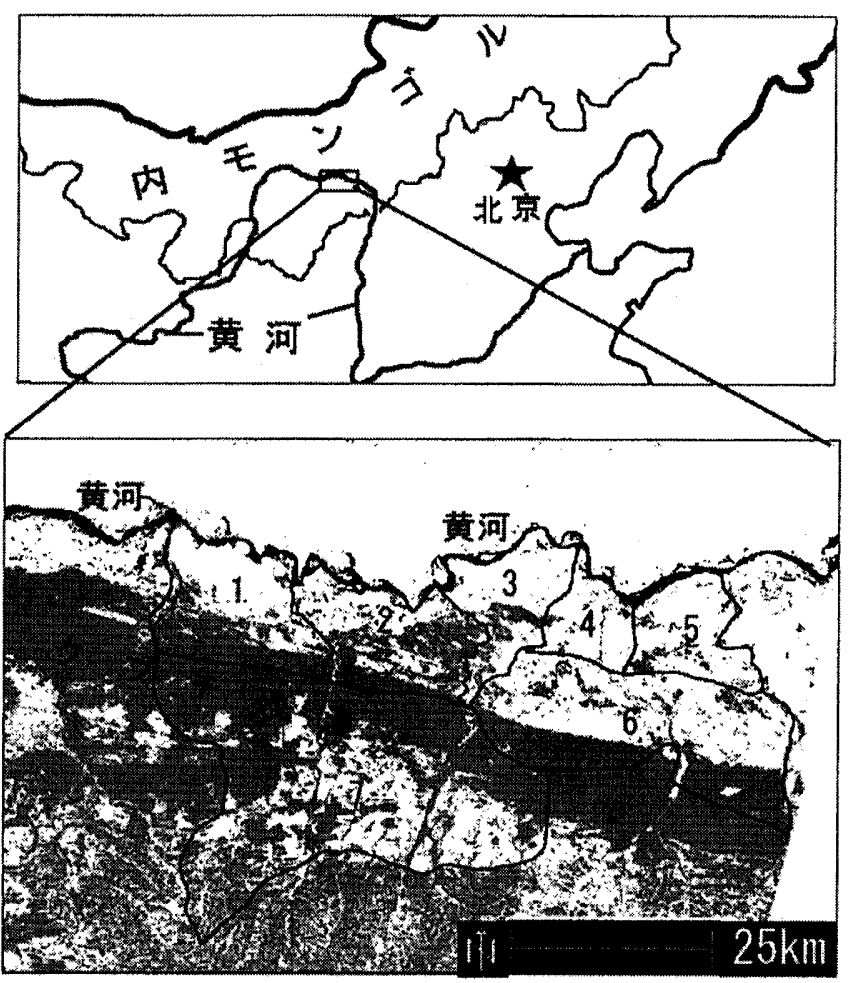

1-中和西郷 ; 2-ウラン郷 ; 3-四村郷 ; 4-ショジンフン郷 ;

5一解放タン郷；6一展旦召郷；7ーソホウト郷

図 1 解析対象領域の地理的位置
一タは生データの画像座標から UTM 座標に変換したものである。幾 何補正誤差(RUS) は 1 ピクセル以内であった。

\section{4. 土地被咟状況について}

\section{（1）土地被覆分類}

土地被覆分類項目の設定については、オルドス地区土地管理局で 2000 年に編集された「オルドス地区土地資源調査・評価報告集」及ぴ 内モンゴル航空リモートセンシング院で 1991 年に作成された「オル ドス地区士地利用現状報告」を参考にした ${ }^{56) 。 ~}$

本報の土地被覆分類では、まず教師なし分類の一つであるクラス ター分析を行った。クラスタリング手法としては、非皆層的クラス タリング法を用いた。さらに、クラスター分析において分類された クラスを教師とし、最尤推定法による、土地被覆分類図を作成した。

教師なし分類の結果を基に最終的な分類項目は水域、濩㜔農地、 天水農地、草地、裸地、砂地の 6 種類の土地被覆タイプとして、土 地被覆分類図を作成した。1986 年に黄河沿岸に分布していた塩害の ための休耕地、1986 年と 2002 年に河川涸水により川床が露出する 場所は裸地に分類した。

（2）土地被覆の経年変化

図 2 に 3 時期のそれぞれの土地被覆分類図を示し、3 時期の土地 被覆状況を表 1 に示す。北部黄河南岸各郷では近年の大規模な水利 施設の整備によって、灌激農地が大幅に增加し、農業生産環境は著 しく改善された。クブチ砂漠周辺地域では、1994 年までに、草地と 裸地開垢の結果として天水農地の面積が大幅に扡大し、草地法減少 している。一方、 3 時期の土地被覆分類結果を比較すると、砂地は 増加し、土地の砂漠化が進行しつつあることが見られる。特に 1986 年から 1994 年にかけて、砂漠が大幅に隣接地域の土地を侵食した状 況が見られる。1994 年から 2002 年にかけて、退耕還草政策が進め られ、砂漠の周辺地域では耕作に適しない天水農地を退耕し、退耕 地に植草活動を行うことによって、草地生態環境の回復が実施され た。2002 年には、草地の面櫝はある程度まで増加した。砂地では植 生に回復しているところも見られ、1986 年の画像と 2002 年の画像 を比較すると、中和西郷北西部にあるモブラガコンデ川下流周辺砂 地の植生回復は顯著であることが判る。

表 1 各土地被覆カテゴリの面積 $\left(\mathrm{k} \mathrm{m}^{2}\right)$

\begin{tabular}{|c|c|c|c|}
\hline & 1986 年 & 1994 年 & 2002 年 \\
\hline 灌睡農地 $*$ & 345.12 & 403.23 & 420.92 \\
\hline 天水農地 $* *$ & 442.82 & 485.93 & 368.52 \\
\hline 草地 & 735.89 & 599.06 & 675.79 \\
\hline 砂地 & 906.33 & 961.35 & 969.05 \\
\hline 裸地 & 62.45 & 26.11 & 56.12 \\
\hline 水域 & 30.27 & 44.32 & 29.60 \\
\hline
\end{tabular}

(注)

*灌溉農地：淮溉システムが整備されており、 農産物の生産量が高い烟地

**天水農地 : 灌溉用水がなく、雨水たけに依存している烟地 

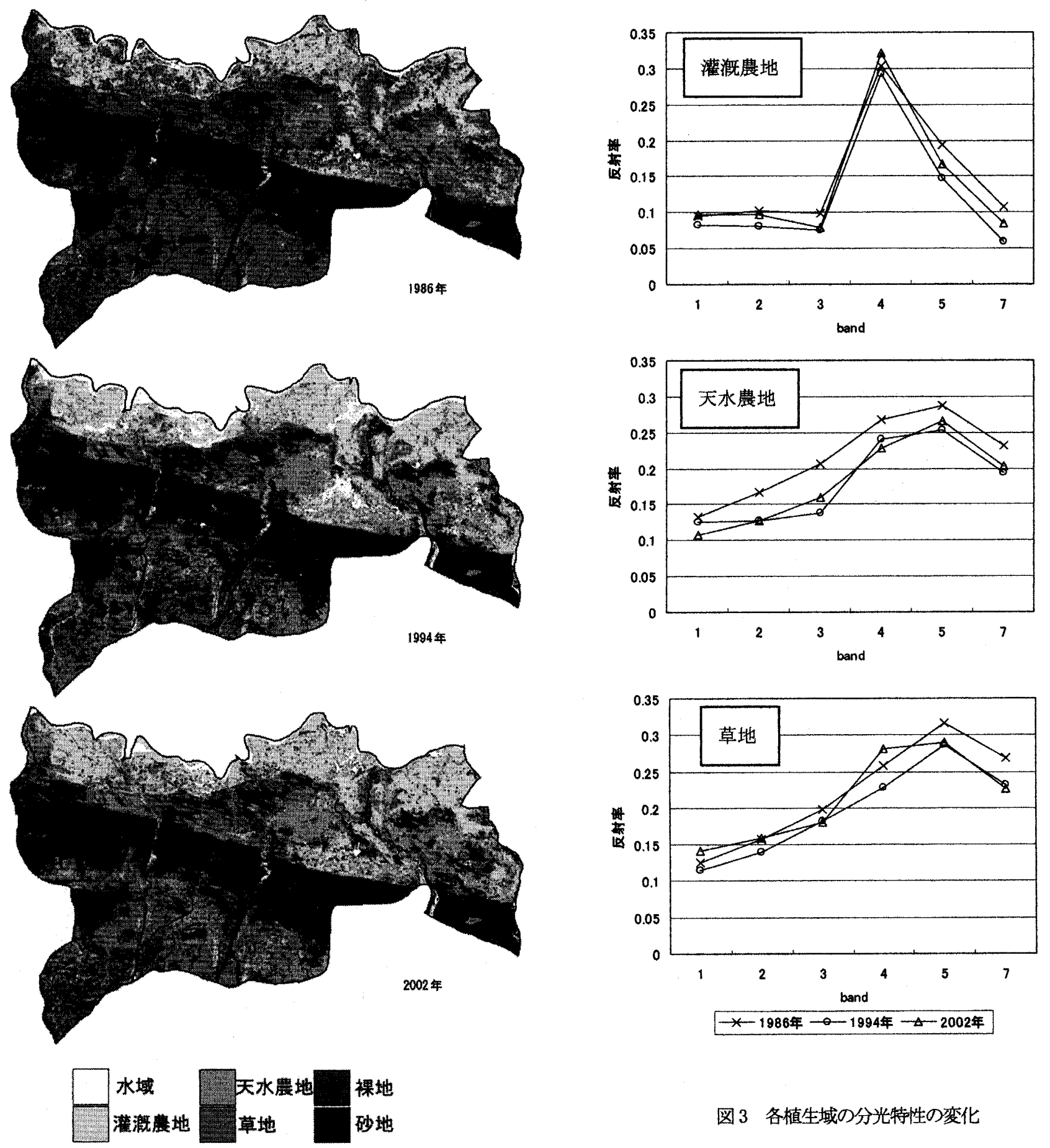

図 2 研究対象エリアの時系列土地被覆分類図

(3) スペクトル解析

ここでは、TM と ETM+データにより、3 時期における植生変化状況 を明らかにするため、異なる土地被覆クラスに対し、各バンドのス ペクトル特性解析を行う。ランドサットデータを緇対值として比較 する場合、Digital Number(DN)のままでは各時期のセンサ一内部設 定が異なるため問題になる。従って、DN から放射輝度 L を計算し、 さらに反射率(Reflectance)を計算して使用する必要がある。放射輝 度は式(1)と(2)で得られる。 
ここでは 3 時期の各植生項目について各バンドの反射率を算出し、 その平均から、スペクトルのバンド特性を解析することによって、 灌溉農地、天水農地及ひ草地の植生変化傾向を推定する。

図 3 に、各植生項目の反射特性の経年変化を示す。ここで, ラン ドサットのバンド 3 (赤色) とバンド 4 （近赤外）の波長带に注目す ると、植物では, バンド 4 はバンド 3 に比べて反射率が大幅に増加 する傾向があり、灌溮農地では植物の量及ひ活性度が高いため、バ ンド3とバンド4の反射率の差は大きくなっている。灌測農地は 1994 年から農地管理が改善され、2002 年まで農産物のバイオマスは高く なりつつあると判断できる。

草地に関しては 1994 年まで一度衰退したが、2002 年に成長状況 がよくなっていたことが分かった。逆に、天水農地の場合には、1994 年の農産物の生産量は増加したと見られるが、2002年まで地力の衰 退につれて生産量は低くなる傾向が見られた。これは、内モンゴル オルドス土地管理局の土地利用調查結果を裹付けている。即ち土地 利用調查報告では、七鄉の天水農地特に新開懇地は土壤表土が $30 \mathrm{~cm}$ 以下で、灌漑措置がなく、生産量が低下しており、農業生産に適し ていないと判断されている゙ ${ }^{\text {)。 }}$

\section{5. 退耕還草地の状況}

（1）各郷の退耕還草地の状況と調查統計資料との比較

オルドス地域では、1992 年から土地荒廃・砂漠化を防止するため に、クブチ砂漠周辺の農業・牧業地域にある耕作条件の德い天水農 地に対して、退耕還草土地利用政策が害施されつつある。耕作の適 否を判断する基準と評価指標を表 2 にまとめる。これらの基淮と指 標は、中国国土資源部「西部大開発土地资源調查評価実施方案」に 基づいて、オルドス土地管理局により制定されたものである ${ }^{6)}$

内モンゴルとオルドスの土地管理機関は土地利用現状、土壇条件 およひ社会経済条件などを考虑して、退耕還草評価指標による退耕 還草地域の区分を行った。中和西郷、ウラン郷、四村郷、ショジン フン郷、解放タン郷の北部は黄河 “南岸平原農業発展区’として、 五郷の南部、展旦召郷およびホストウ郷は “風食砂漠化退耕区' して区分した。本報では、ランドサットデータによる七郷の土地被 覆分類結果から、郷界別に土地被覆情報を抽出し、2002 年までの各 郷の退耕還草の実態を調查する。さらに、各郷の天水農地の変化を
定量的に解析するとともに、現地の退耕還草計画実施状況の調查報 告との対応を比較検謗する。上記の調查報告は 2000 年 8 月にオルド ス土地管理局に行われた土地資源調査に基づいて編集されたもので ある。本報で利用した行政界地理情報は、内モンゴル航空りモート センシング院から入手したオルドス地区のベクトル地図から抽出さ れた。

調查統計資料との対応は郷毎に検討し、その結果を表 3 に示す。 ランドサットデータによる天水農地の変遷の推定には 1994 年と 2002 年のデータを使用している。ランドサットデータから推定した 天水農地から草地への変化地寸なわち退耕還草地は各郷ともやや大 きめではあるが調查統計資料と同様の傾向を示している。大きめに 推定されているのは、調查統計值が 2000 年のデータであり、その後、 さらに退耕環草が進んでいるためであると考えられる。 表 2 耕地の評価指標

\begin{tabular}{|c|c|c|}
\hline 評価指標 & 耕作に適 & 退耕地 \\
\hline 砂の侵食程度 & $<20 \%$ & $>20 \%$ \\
\hline 表土厚さ & $>30 \mathrm{~cm}$ & $<30 \mathrm{~cm}$ \\
\hline 土壤有機質 & $>0.6 \%$ & $<0.6 \%$ \\
\hline 土壤品質 & 石ころ含墨 <15\% & 石こ万含量 > $15 \%$ \\
\hline 温度条件 & 凍害哃威無 & 凍害哃威有 \\
\hline 生産量 & 中产一低産 & 低産以下 \\
\hline
\end{tabular}

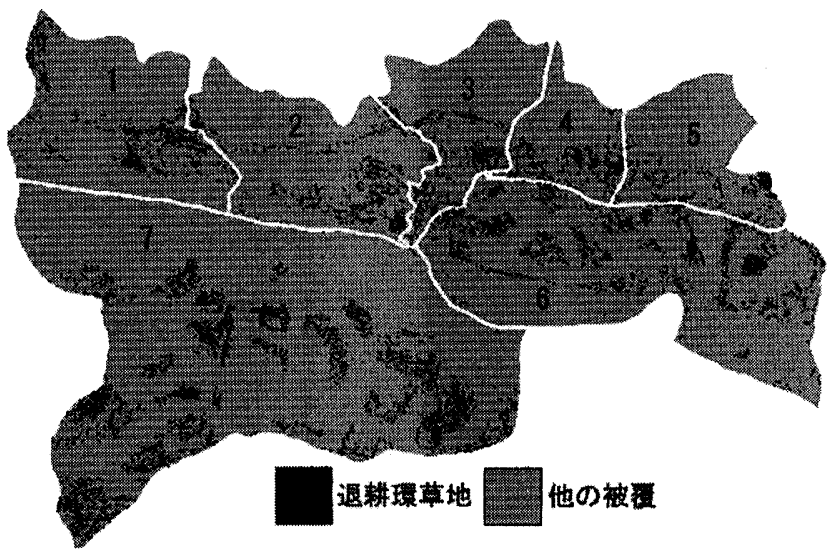

図 4 推定した退耕環草地の分布状況

表 3 ランドサットデータから推定した郷別の土地被覆変化と統計值 $\left(\mathrm{k} \mathrm{m}^{2}\right)$

\begin{tabular}{|c|c|c|c|c|c|c|c|}
\hline & \multicolumn{5}{|c|}{ ランドサットデータからの推定值(1994年-2002年) } & \multicolumn{2}{|c|}{ 調查統計值 (2000年まで) } \\
\hline & $\begin{array}{c}\text { 天水農地 } \\
\text { ，砂地 }\end{array}$ & $\begin{array}{c}\text { 天水農地 } \\
\rightarrow \text { 裸地 }\end{array}$ & 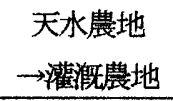 & $\begin{array}{c}\text { 天水農地 } \rightarrow \text { 草地 } \\
\text { (退耕環草地) }\end{array}$ & 末変化天水農地 & 退耕還草地 & 末変化天水農地 \\
\hline ホソウト郷 & 3.7 & 3.3 & 2.2 & 29.9 & 103.4 & 24.8 & 100.7 \\
\hline 展旦召郷 & 3.1 & 3.0 & 1.4 & 28.4 & 135.7 & 25.3 & 138. 4 \\
\hline 四村郷 & 1.0 & 1.6 & 1.6 & 3.1 & 39.2 & 2.5 & 36.9 \\
\hline 解放テン郷 & 0.6 & 1.9 & 3.1 & 2.6 & 24.0 & 2.4 & 22.2 \\
\hline 昭君フン郷 & 0.0 & 1.0 & 1.5 & 3.0 & 20.2 & 2.1 & 21.3 \\
\hline 中和西郷 & 1.0 & 2.0 & 1.7 & 3.3 & 30.6 & 3.0 & 30.3 \\
\hline ウラン郷 & 0.6 & 0.8 & 2.5 & 4.1 & 34.1 & 3.7 & 31.1 \\
\hline
\end{tabular}


1994 年と 2002 年のデータから抽出した退耕還草地の分布状況を 図 4 に示す。ほとんどの退耕還草地は黄河沿岸五郷南部、展旦召郷 およびホソトウ郷に分布している。このうちホントウ郷と展旦召郷 の退耕還草地は天水農地の $16 \%$ 以上を占めており、他の郷は $7 \%$ -9\%程度である。3 時期の土地被覆変化の推定結果を見孔ば、1994 年まで砂漠化の進行は激しく、1994 年と 2002 年の間に砂地の増加 は顕著には見られない。このことから現地での退耕還草事業などの 砂漠化対策の成果が表れていると思われる。

（2）植生指標(NDVI)による退耕還草地の植生状況の評価

退耕還草事業の効果を検証するため、退耕還草地の植物生育状况 の評価を行う。ここでは、植物の量と活性度を反映する植生指数NDVI を導入した。図 4 に示している退耕還草地区域の 3 時期の NDVI を式 (4)で算出した。

$$
N D V I=\frac{\text { Band } 4-\text { Band } 3}{\text { Band } 4+\text { Band } 3} \times 100+100
$$

NDVI の分布状况を図 5 に示す。各時期による植生の生育状況の違 いが NDVI の分布傾向に現れている。2002 年は退耕還草地の植物の 生育がよく、NDVI 値が高い傾向を示している。退耕辠草地における 土地管理の改善と植草活動による植生の回復が良い状況になってい ると思われる。NDVI を比較する方法は植生変化状況を把握するため の一つ方法であると考えられる。しかし、NDVI は地域降水量の影響 を受けやすく、過大あるいは過小評価されることもある。内モンゴ 儿南西部半畭燥地域では、降水の大部分は 7 月〜9 月に集中する。 そこで、内モンゴル気象局によって観測された七郷の所属県一ダラ 卜県の 1986 年、1994 年及び 2002 年夏期の降水量情報を参考にした (表 4 参照)。ダラト県の年平均が $350 \mathrm{~mm}$ 程度であることを考えると， 1994 年夏期は降水量が大きく、2002 年恃平年並みの降雨であった。

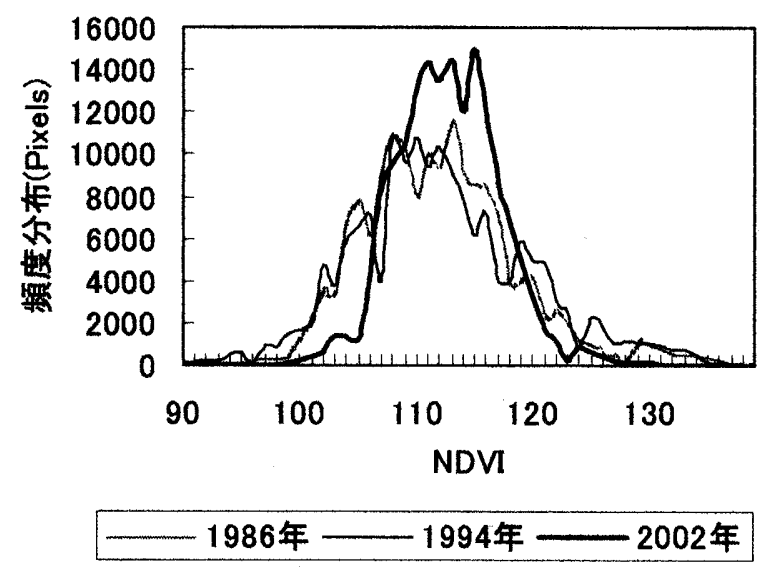

図 5 退耕還草地の NDVI の分布状況

表 4 ダラト県降水データ $(\mathrm{mm})$

\begin{tabular}{|c|c|c|}
\hline & 7 月 & 8 月 \\
\hline 1986 年 & 41.2 & 43.9 \\
\hline 1994 年 & 159.7 & 167.9 \\
\hline 2002 年 & 50.0 & 63.0 \\
\hline
\end{tabular}

よって、2002 年の NDVI が大きかったのは降水量の影響ではなく、 人工植草活動により退耕還草地の植生が回復していると判断できる。

\section{6. 砂漠化地域のテクスチャ解析}

砂漠化の進行状況を図 6 に示す。この地域では南部及び中部で砂 漠化の進行が著しく、北部の黄河沿岸地区では変化がほとんど見ら れない。図6に示しているS1、S2 は、開墾農地から砂地に変化した エリアと推定される。また、S はクブチ砂漠奥部の旧来からの砂地 である。ここでは、砂漠化した土地の空間的特徴变化に着目し、TM、 $\mathrm{ETM}+$ 画像のテクスチャを抽出し、3 時期の土地被覆状况や土地形態 との関係について検討する。

リモートセンシング画像判読においては、画像に表れる模様すな わちテクスチャ(texture)の認識によって多くの情報を得られるこ とが知られている。ここでは、統計的なテクスチャ特街の一つの計 算法として、濃度共起行列(grey level co-occurrence matrix)を用い る。濃度共起行列とは，画像内の濃度 $\mathrm{i}$ をるつ画素から一定の変位 $\mathrm{d}=(\mathrm{r}, \theta)$ だけ離れた画素の濃度値が $\mathrm{j}$ である確率 $\mathrm{P}_{8}(\mathrm{i}, \mathrm{j})$ を求めたも のである7。ここでは濃度共起行列から得られる 12 種類の特徽量の なかで，経験的に最も有効であった angular second moment(ASM，角 度別 2 次モーメント)の特徴量を選択し用いる。ASM はテクスチャの 均一性を表す特徽であり、その值が大きいほど、テクスチャの均質 性嵪くなる。ASM 值は次の式から算出する。

$$
A S M=\sum_{i=0}^{n-1} \sum_{j=0}^{n-1}\left\{P_{\delta}(i, j)\right\}^{2}
$$

本報では、まず水域、砂地、櫵激農地、草地、天水農地の代表的 な五つのエリアに対し、ランドサット画像のテクスチャを抽出し、 それそれのエリアの土地被覆状況について比較検討を行う。図 7 に 水域、砂地、灌激農地、草地、天水農地の ASM の変化傾向を示す。 水域、砂地は各植生域に比べて、高い均翼性を持っており、水域と 砂地の形態とよく対応している。植生域については、植物の分布密

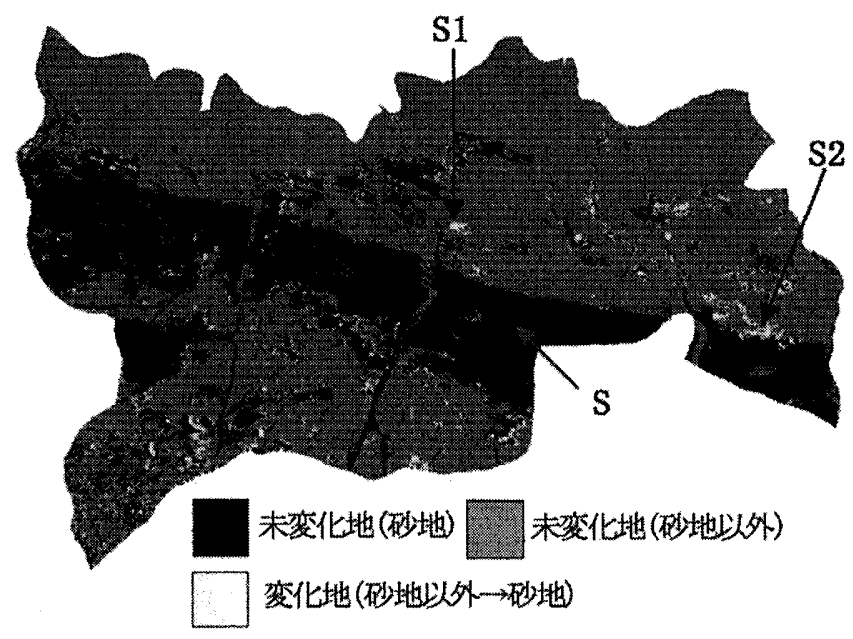

図 61986 年〜2002 年における砂地の変化 
度によって、地表面のテクスチャ特徴すなわち均質性が違う。本研 究の対象エリアにある天水農地はテクスチャの均一性が最も低いと 見られる。これは内モンゴルの半乾燥地帯にある天水農地では農作 物の密度が低く、植物と大きく露出している土袞が混在している状 況に一致している。

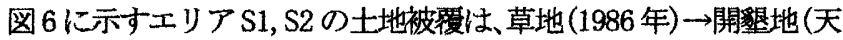
水農地, 1994 年) $\rightarrow$ 砂地 (2002 年)の段階で変化している。また、エリ ア S は旧来からの砂漠で、1986 年から 2002 年の間も砂地のままで ある。式(5)によりエリア S, S1, S2 のバンド毎の ASM 值を算出した。

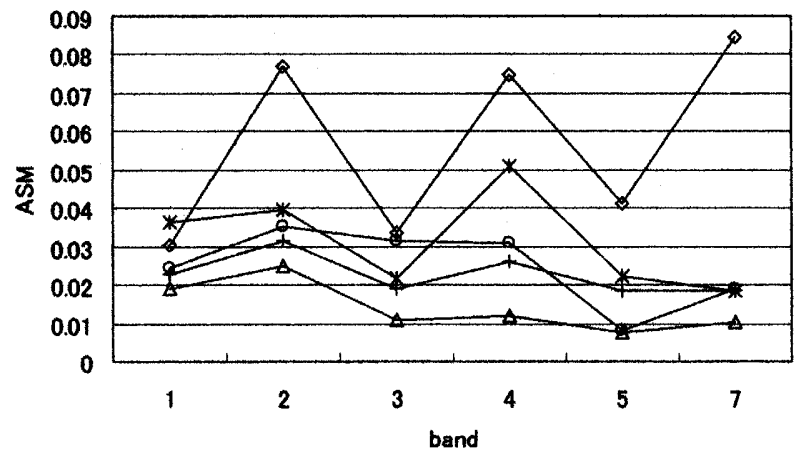

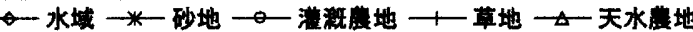

図 7 各土地被覆タイブのテクスチャ特徽
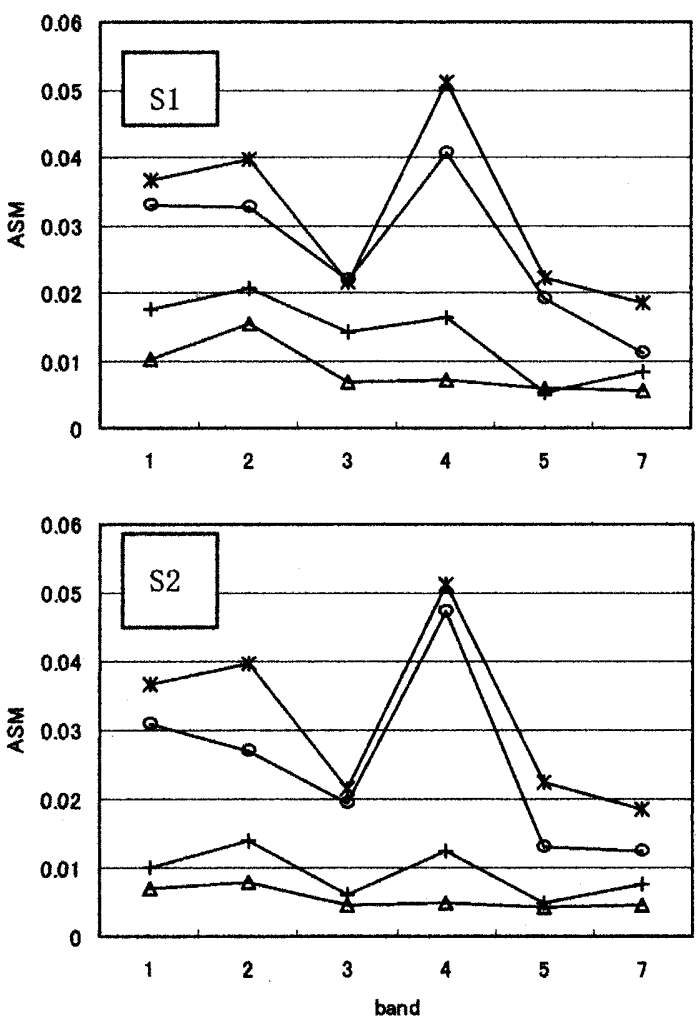

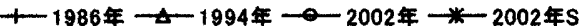

図 8 砂漠化地域の各時期のテクスチャ特徽
図 8 に示すように各土地被嗄カテゴリの ASM 值を比較すると、砂地 エリア S のテクスチャの均質性が最もよいことは明確である。2002 年の S1, S2 の ASM 值は 1986 年、1994 年に比べて大きくなり、砂漠 奥部エリア S のテクスチャ特徴によく似ている傾向がみられる。即 ちこの二䉪所の土地状況は砂地になっていると考えられる。1994年 の天水農地の ASM 值は最も小さいことから、砂漠周辺のほとんどの 開辴地が管理不良と栽植密度の低さのため、植物と大きく露出して いる土壤が混在しており、いわゆる地表面被覆が不均一になってい ることが分かった。

\section{7. まとめ}

本報では、ランドサットデータを用い、1986 年、1994 年及び 2002 年夏期の土地被覆図を作成した。また、現地の土地利用現状調查報 告を参考にして内モンゴル黄河流域七鄉の土地被覆変化と砂漠化の 状況を解析した。その結果、以下の点が明らかになった。

（1）濩貦農地が増加する一方で、砂漠化も進行していることが確か められた。

（2）スペクトルのバンド特性を解析することによって、植生域の植 生変化傾向を推定した。2002 年まで灌㴔農地の生産量は高く なりつつあるが、天水農地の農作物の生育状況は悪くなってき ていることが分かった。

（3） ランドサットデータにより 1994 年〜2002 年におけける郷界別の 天水農地の変遷情報を抽出するとともにこれと既存統計によ る退耕啐草地データとの対応について検討し、砂漠化対策とし ての退耕還草活動の効果を検証した。さらに、植生指標 NDVI を用いて 2002 年までの退耕還草地の植物の成育状況を謂べ、 植生が回復している状況を示した。

（4）砂漠化地域に推定したエリアに対し、ランドサット画像のテク スチャ指標を抽出し、それらのエリアにおける 3 時期の土地被 覆形態が大きく変わったことを明らかにした。2002 年の地表 面のテクスチャ特徴は砂漠奥部エリアの特徽に似てきたこと が分かり、砂漠周辺の開墾農地の砂漠化の実態を検証した。

参考文献

1) 立入 郁, 衣笠聡史 : 偵察衛星 CORONA のデータを用いた中国 内蒙古自治区奈曼旗の砂漠化のモニタリング, 写真測量とリモ ートセンシング, Vol.39(5), pp4-13.

2）秋山 㑆，川村健介: 内蒙古草原植生変化・土地少化，シス テム農学（J , JASS），19(3)，2003 12

3）国友淳子，森本幸裕：リモートセンシングによる中国毛鳥素 沙地における植生量の定量評価と季節変動の解析，第13 回環 境情報科学碖文集、pp115-120，1999

4）厳 網林，森本淳子，吉田浩之：中国内蒙古自治区コル チン砂地における砂漠化進行土地の景観生態的分析，2002 年 度森基金助成報告畫

5）オルドス土地管理局：「オルドス地区土地凟源調査・評価報告 集」,P55-67,2000

6）内モンゴル航空りモートセンシング院 :「オルドス地区土地利 用現状調查報告」, 1991

7）高木幹雄ら：「画像解析ハンドブック」,pp517-520, 東京大学 出版会, 1991 